\title{
Originals
}

\section{Lowering fatty acids potentiates acute insulin response in first degree relatives of people with Type II diabetes}

\author{
G. Paolisso ${ }^{1}$, M. R. Tagliamonte ${ }^{1}$, M. R. Rizzo ${ }^{1}$, P. Gualdiero ${ }^{1}$, F. Saccomanno ${ }^{1}$, A. Gambardella ${ }^{1}$, D. Giugliano ${ }^{1}$, \\ F. D'Onofrio ${ }^{1}$, B. V. Howard ${ }^{2}$ \\ ${ }^{1}$ Department of Geriatric Medicine and Metabolic Diseases, IInd University of Naples, Naples, Italy \\ ${ }^{2}$ Medlantic Research Institute, Washington, USA
}

\begin{abstract}
Summary Studies have shown that a high plasma non-esterified fatty acid concentration may inhibit glucose induced insulin secretion in vitro and in vivo. The effect of lowering the fatty acid concentration on the acute insulin response was investigated in first degree relatives of people with Type II diabetes in a double-blind, randomised, placebo-controlled trial. Fifty first degree relatives of people with Type II diabetes volunteered for the study. Twenty five were given acipimox ( $250 \mathrm{mg} /$ day, four times daily) and 25 placebo. The group treated with acipimox had a lower 2-h plasma glucose concentration $(6.1 \pm 0.2$ vs $7.7 \pm 0.3 \mathrm{vs} \mathrm{mmol} / 1, p<0.01)$; better insulin-mediated glucose uptake $(35.4 \pm 0.5$ vs $28.3 \pm 0.4 \mu \mathrm{mol} / \mathrm{kg}$ fat free mass per min, $p<0.01$ ), acute insulin response $(68 \pm 4.4$ vs $46 \pm 7.3 \mathrm{mU} / \mathrm{l}, p<0.01)$ and respiratory quotient $(0.81 \pm 0.02$ vs $0.77 \pm 0.03, p<0.05)$; and a rise in the plasma glucagon (164 \pm 63 vs $134 \pm 72 \mathrm{ng} /$ $1, \quad p<0.05), \quad$ growth hormone $(1.31 \pm 0.13$ vs $0.97 \pm 0.21 \mu \mathrm{g} / 1, p<0.03)$ and cortisol $(325 \pm 41 \mathrm{vs}$ $284 \pm 139 \mathrm{nmol} / \mathrm{l}, p<0.05)$ concentrations. The differ-
\end{abstract}

ence in the acute insulin response persisted, even after adjustment for the 2-h plasma glucose concentration, insulin-mediated glucose uptake, the fasting plasma glucagon concentration and the growth hormone concentration $(p<0.05)$. In a subgroup of eight patients acipimox was compared with acipimox plus intralipid. The acute insulin response $(44 \pm 5.1$ vs $71 \pm 5.3 \mathrm{mU} / \mathrm{l}, p<0.01)$ and the insulin-mediated glucose uptake $(27.4 \pm 0.4 \mathrm{vs} 36.7 \pm 0.5 \mu \mathrm{mol} / \mathrm{kg}$ fat free mass per min, $p<0.003$ ) were lower with acipimox plus intralipid treatment than with acipimox alone. It is concluded that long term acipimox treatment lowers the plasma fasting free fatty acid concentration and improves the acute insulin response and the insulin mediated glucose uptake. [Diabetologia (1998) 41: 1127-1132]

Keywords Free fatty acids, acipimox, acute insulin response, Type II diabetes mellitus, insulin-mediated glucose uptake.
It is widely accepted that non-esterified fatty acids inhibit insulin-mediated glucose uptake [1-2]. Despite this evidence, the effect of non-esterified fatty acids on the development of Type II diabetes mellitus was found to be independent of insulin-mediated glucose uptake. Interestingly, by adding the acute insulin response to the covariates tested, the fasting plasma

Received: 27 January 1998 and in final revised form 29 April 1998

Corresponding author: Dr. G. Paolisso, Department of Geriatric Medicine and Metabolic Diseases, Servizio di Astanteria Medica, Piazza Miraglia 2, I-80138 Napoli, Italy non-esterified fatty acids concentration lost its significance as a risk factor for the development of Type II diabetes mellitus [3]. These results suggest that a high concentration of non-esterified fatty acids may be important in explaining the beta cell dysfunction that occurs in the development of Type II diabetes. Nevertheless, the relation between non-esterified fatty acids and insulin secretion is still debated [4-10].

Healthy first degree relatives of people with Type II diabetes have been shown to be at higher risk for the development of this form of diabetes than healthy subjects without a family history of the disease [11-13]. Whether a raised fasting plasma of non-esterified fatty acids concentration plays a pathophysi- 
ological role in first degree relatives of people with Type II diabetes remains to be investigated.

In this study we investigated the part played by a high fasting plasma concentration of non-esterified fatty acids in insulin secretion and action in 50 first degree relatives of people with Type II diabetes. In 25 subjects, the effect of acipimox - a drug that lowers the plasma of non-esterified fatty acids concentration - on acute insulin response and action was also investigated.

\section{Subjects and methods}

Subjects. Fifty first degree relatives of people with Type II diabetes volunteered for the study (Table 1). All were recruited through patients attending the diabetes unit of our department. In all cases, only one parent had Type II diabetes, and none had a brother or sister with the discorder. Participants were lean and were not diabetics according to World Health Organization criteria (Table 1) [14]. Obese subjects or those who smoked were not recruited. None of the participants had taken any drugs in the four weeks preceding the tests. All participants were studied as inpatients, and throughout the study periods consumed a weight-maintaining diet consisting of $50 \%$ carbohydrates, $30 \%$ lipids and $20 \%$ proteins. All individuals gave informed consent before participating in the study, which was approved by the ethical committee of our institution.

Anthropometric determinations. Weight and height were measured by standard techniques. Body fat and fat free mass were measured using a four terminal bioimpedance analyser (RJL Spectrum Bioelectrical Impedance, BIA 101 /SC Akern; RJL System; Florence, Italy). The body mass index (BMI) was calculated as the body weight $(\mathrm{kg})$ divided by height $\left(\mathrm{m}^{2}\right)$. The waist circumference was measured with plastic tape at the midpoint between the lower rib margin and the iliac crest (normal umbilical level) and the hip circumference at the level of the trochanter. Both circumferences were measured to the nearest $0.5 \mathrm{~cm}$, and the ratio between them provided the waist/hip ratio.

Experimental design. The study comprised two parts. Firstly, the effect of acipimox on the acute insulin response was compared with that of placebo. Secondly, the effect of acipimox on the acute insulin response was compared with that of acipimox plus intralipid.

Acipimox vs placebo. The study was designed as a doubleblind, randomised placebo-controlled trial. A one week run-in period was observed for each subject. During this period subjects did not take drugs, participate in strenuous physical activity or drink alcohol and coffee. At the end of the run-in period, subjects were admitted to hospital and blood samples were drawn for determining baseline fasting plasma metabolite values. At this time, each patient was randomly assigned to treatment with placebo $(n=25)$ or acipimox $(n=25)$ (Olbetam; Pharmacia Uppsala, Sweden) given four times daily starting at 06.00 hours. Both treatment periods lasted one week. At baseline, and at the end of the treatment periods, the acute insulin response and insulin-mediated glucose uptake were measured. The acute insulin response was assessed by intravenous glucose test as previously reported [9]. Briefly, glucose was given as a bolus $(0.3 \mathrm{~g} / \mathrm{kg}$ body weight over 3 minutes $)$ and a blood
Table 1. Clinical characteristics of the study groups at baseline

\begin{tabular}{lcc}
\hline & $\begin{array}{c}\text { Placebo } \\
(n=25)\end{array}$ & $\begin{array}{c}\text { Acipimox } \\
(n=25)\end{array}$ \\
\hline Age (years) & $43.7 \pm 3.4$ & $44.2 \pm 4.4$ \\
Gender $(\mathrm{M} / \mathrm{F})$ & $13 / 12$ & $14 / 11$ \\
Body mass index $\left(\mathrm{kg} / \mathrm{m}^{2}\right)$ & $25.1 \pm 0.2$ & $24.9 \pm 0.4$ \\
Body fat $(\%)$ & $22 \pm 0.2$ & $22 \pm 0.3$ \\
Waist/hip ratio & $0.83 \pm 0.02$ & $0.82 \pm 0.03$ \\
Fasting plasma glucose (mmol/l) & $5.2 \pm 0.3$ & $5.3 \pm 0.3$ \\
Fasting plasma insulin (pmol/l) & $83 \pm 14$ & $81 \pm 10$ \\
2-h plasma glucose (mmol/l) & $8.1 \pm 0.5$ & $7.8 \pm 0.6$ \\
Insulin-mediated glucose intake & & \\
( $\mu$ mol/kg mass per min) & $28.1 \pm 0.5$ & $27.8 \pm 0.6$ \\
Acute insulin response (mU/l) & $49 \pm 6.1$ & $46 \pm 5.8$ \\
Fasting plasma non-esterified: & & \\
fatty acid ( $\mu$ mol/l) & $718 \pm 215$ & $789 \pm 276$ \\
Fasting plasma glucagon $(\mathrm{ng} / \mathrm{l})$ & $120 \pm 67$ & $136 \pm 71$ \\
Fasting plasma growth hormone $(\mu \mathrm{g} / \mathrm{l})$ & $0.95 \pm 0.21$ & $0.98 \pm 0.20$ \\
Fasting plasma cortisol (nmol/l) & $288 \pm 31$ & $281 \pm 36$ \\
Respiratory quotient & $0.77 \pm 0.03$ & $0.76 \pm 0.04$
\end{tabular}

All results are mean \pm SD.

No significant differences between the two groups were found Respiratory quotient was adjusted for age, fat mass and free fatty mass

sample was drawn each minute from 1 to $15 \mathrm{~min}$. Insulin action was measured using the euglycaemic hyperinsulinaemic glucose clamp technique. In this test a fixed insulin infusion rate (7.1 pmol/kg per min for $120 \mathrm{~min}$; Humulin R; Eli-Lilly, Florence, Italy) and a variable amount of glucose (as a $20 \%$ solution) were delivered. Before and during the clamp procedure, changes in the respiratory quotient (Deltatrac; Datex, Milan, Italy) were also measured [15]. Both the intravenous glucose test and euglycaemic glucose clamp were done in random order in the whole group of subjects. Glucose infusion and euglycaemic glucose clamp were undertaken in random order with at least a $4 \mathrm{~h}$ wash-out period between each test. The last placebo and acipimox pills were given at midnight of the day before starting the investigations.

Acipimox vs acipimox plus intralipid. At the end of the previous study, and after a 1 week wash-out period, a subgroup of eight subjects participated in a study of the effect of acipimox treatment on the acute insulin response in the absence of change in the non-esterified fatty acid plasma concentration. All subjects were treated with acipimox $(250 \mathrm{mg} /$ day, four times daily starting at 06.00 a.m.) and in the last three days, plasma non-esterified fatty acid concentrations were kept close to basal values through a $10 \%$ intralipid infusion (10\% triglyceride emulsion; Intralipid, Pharmacia, Sweden) at a rate of $0.4 \mathrm{ml} / \mathrm{min}$. At the end of this period all subjects underwent an intravenous glucose test and a euglycaemic glucose clamp proceeded for the determination of the acute insulin response and insulin-mediated glucose uptake respectively.

All studies were performed after a 12 to 14-h fast and with the subjects on bed rest and in the supine position for the duration of the testing. An antecubital vein in one arm was cannulated with a 19 gauge catheter for administration of the various agents, and was kept open by a slow infusion of $0.9 \%$ sodium chloride. All blood samples were drawn from a contralateral vein through a three-way stop cock, to avoid additional veni- 
puncture during the infusion. Three samples were obtained before the start of the infusion, and the mean of the three was considered as the basal value.

Blood sampling. Blood samples were collected in pre-chilled tubes. These were kept in an ice bath until the end of the study were centrifuged immediately after each experiment. The resultant plasma was stored at $-20^{\circ} \mathrm{C}$ for future hormone assay. Plasma glucose concentrations were measured by a glucose oxidase method adapted for use with a Beckman glucose analyser (Beckman, Fullerton, Calif., USA). The serum specific plasma insulin concentration was measured by commercial double antibody radioimmunoassay (Linco Research; USA; coefficient of variation $(\mathrm{cv})=4.7 \%)$ in which cross-reactivity with proinsulin is $0.2 \%$. The lower limit of sensitivity of the Linco assay is $14.4 \mathrm{pmol} / \mathrm{l}$. Plasma glucagon ( $\mathrm{cv}=4.7 \pm 0.8 \%)$, growth hormone $(\mathrm{cv}=3.8 \pm 0.4 \%)$ and cortisol $(\mathrm{cv}=3.3 \pm 0.5 \%)$ concentrations were measured by radioimmunoassay (Sorin Biomedica, Milan, Italy). Fasting plasma non-esterified fatty acid values were derived using the mean of four different samples drawn at 10 -min intervals. Non-esterified fatty acid concentrations were measured in triplicate in each sample, according to the method of Dole and Meinertz [16].

Calculations and statistical analyses. The acute insulin response to the glucose pulse was calculated as the incremental area of the post-glucose insulin concentrations from 3 to $7 \mathrm{~min}-\mathrm{de}$ scribed elsewhere [9]. Statistical analyses were performed using the SOLO (BMDP, Cork, Republic of Ireland) software package. Data were analysed by a doctor who was unaware of the randomisation sequence or the subjects' symptoms. All values are presented as mean $\pm \mathrm{SD}$. Student's two-tailed $t$ tests for paired data were used to compare the effects of acipimox and placebo within each group of subjects. Analysis of variance (ANOVA) was used to evaluate the different results from the two groups. Analysis of covariance (ANCOVA) allowed us to adjust the respiratory quotient for age, fat mass and fat free mass and to adjust the acute insulin response for 2-h plasma glucose values, fasting plasma glucagon and growth hormone concentrations and insulin-mediated glucose uptake. For each subject, only adjusted respiratory quotient values were reported and were calculated as the mean value for the group plus the difference between the measured and the predicted values. Correlations are Pearson product moment correlations. Partial correlations were used to examine the relation between two variables independently of covariates. Multivariate analysis allowed us to study the independent contributions of different covariates to the acute insulin response. A $p$ value less than 0.05 was chosen as the level of significance.

\section{Results}

Main study data. Clinical characteristics are reported in Table 1. Subjects were lean, were not glucose intolerant, but were insulin resistant. In the main study $(n=50)$, fasting plasma non-esterified fatty acid concentrations were significantly correlated with body fat $(r=0.45, p<0.001)$, fasting plasma insulin concentration $(\mathrm{r}=0.37, p<0.008)$, insulin-mediated glucose uptake $(r=-0.47, p<0.001)$, acute insulin response $(r=-0.42, p<0.003)$ (Fig. 1$)$ and the basal respiratory quotient $(r=-0.46, p<0.001)$. In contrast, no significant correlation was found between the fast-

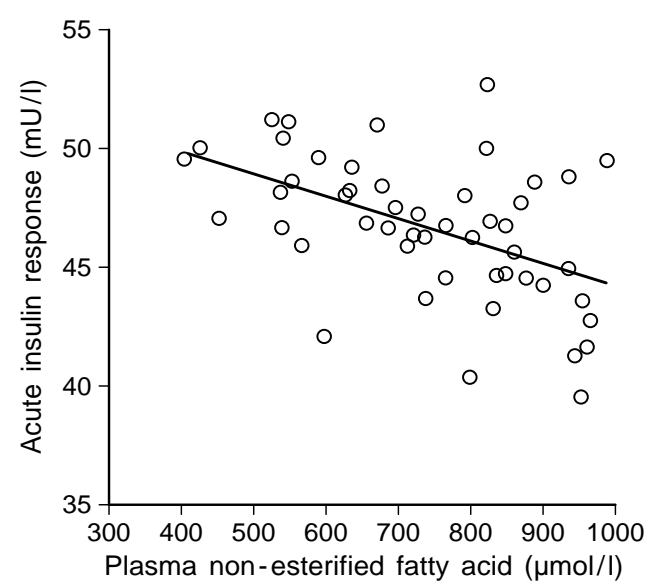

Fig. 1. Simple correlation between the fasting plasma non-esterified fatty acid concentration and the acute insulin response in the whole group of subjects $(n=50)$ before randomisation $(r=-0.42 p<0.003)$

ing plasma non-esterified fatty acids concentration and age $(r=0.25, p<0.08)$. Independently of body fat, the fasting and 2-h plasma glucose concentrations and insulin mediated glucose uptake, the fasting plasma non-esterified fatty acids concentration was still significantly correlated with the acute insulin response $(r=-0.31, p<0.03)$. The independent contribution of the main anthropometric and metabolic parameters to the acute insulin response was studied by multivariate analysis. A model using age, gender, body fat, fasting, and 2-h plasma glucose and insulinmediated glucose uptake explains $53 \%$ of the variability. In such a model, body fat $(t=3.88, p<0.003)$, 2-h plasma glucose $(t=2.37, p<0.05)$ and insulinmediated glucose uptake $(t=-2.67, p<0.04)$ were associated with the acute insulin response. Additing the non-esterified fatty acid concentration yielded a model that explained $68 \%$ of the variability. In the latter model, body fat, 2-h plasma glucose, insulinmediated glucose uptake non-esterified fatty acid values and were all significantly associated with the acute insulin response. In particular, the fasting plasma non-esterified fatty acids concentration $(t=-3.37, p<0.01)$ explained $23 \%$ of the variability in the acute insulin response.

Effects of acipimox. At baseline, no significant differences between groups were found in any of the parameters studied (Table 1 ). In the placebo group, anthropometric (data not shown), hormonal and metabolic parameters were similar at baseline and at the end of the study. In fact, the fasting plasma glucose $(5.2 \pm 0.3$ vs $5.3 \pm 0.3 \mathrm{mmol} / \mathrm{l}, p=\mathrm{NS})$ and non-esterified fatty acid $(718 \pm 215$ vs $733 \pm 233 \mu \mathrm{mol} / 1$, $p=\mathrm{NS}$ ) concentrations, insulin-mediated glucose uptake $(28.1 \pm 0.5 \mathrm{vs} 28.3 \pm 0.8 \mu \mathrm{mol} / \mathrm{kg}$ fat free mass per $\min , p=\mathrm{NS})$ and acute insulin response $(49 \pm 6.1 \mathrm{vs}$ $46 \pm 7.3 \mathrm{mU} / 1, \quad p=\mathrm{NS}$ ), fasting plasma glucagon 
Table 2. Metabolic and hormonal effects of acipimox treatment $(n=25)$

\begin{tabular}{lccc}
\hline & Baseline & Acipimox & $p$ \\
\hline $\begin{array}{l}\text { Non-esterified fatty acid } \\
\text { ( } \mu \text { mol/l) }\end{array}$ & $789 \pm 276$ & $467 \pm 178$ & $<0.001$ \\
$\begin{array}{l}\text { Fasting plasma glucose } \\
\text { (mmol/l) }\end{array}$ & $5.3 \pm 0.3$ & $5.0 \pm 0.2$ & $<0.09$ \\
$\begin{array}{l}\text { Fasting plasma insulin } \\
\text { (pmol/l) }\end{array}$ & $81 \pm 10$ & $78 \pm 15$ & $<0.65$ \\
$\begin{array}{l}\text { 2-hour plasma glucose } \\
\text { (mmol/l) }\end{array}$ & $7.8 \pm 0.3$ & $6.1 \pm 0.2$ & $<0.01$ \\
$\begin{array}{l}\text { Insulin-mediated glucose } \\
\text { uptake ( } \mu \text { mol/kg fat free } \\
\text { mass per min) }\end{array}$ & $27.8 \pm 0.6$ & $35.4 \pm 0.5$ & $<0.05$ \\
$\begin{array}{l}\text { Acute insulin response (mU/l) } \\
\text { Fasting plasma glucagon (ng/l) }\end{array}$ & $46 \pm 5.8$ & $68 \pm 4.4$ & $<0.01$ \\
$\begin{array}{l}\text { Fasting plasma growth } \\
\text { hormone ( } \mu \text { g/l) }\end{array}$ & $0.98 \pm 0.20$ & $1.31 \pm 0.13$ & $<0.03$ \\
$\begin{array}{l}\text { Fasting plasma cortisol } \\
\text { (nmol/l) }\end{array}$ & $281 \pm 36$ & $325 \pm 41$ & $<0.05$ \\
$\begin{array}{l}\text { Respiratory quotient } \\
\text { All results are mean } \pm \text { SD }\end{array}$ & $0.76 \pm 0.04$ & $0.81 \pm 0.02$ & $<0.03$ \\
\hline
\end{tabular}

All results are mean \pm SD.

Respiratory quotient was adjusted for age, fat mass, free fatty mass

$(120 \pm 67$ vs $127 \pm 71 \mathrm{ng} / \mathrm{l}, p=\mathrm{NS})$ and growth hormone $(0.95 \pm 0.14$ vs $0.93 \pm 0.18 \mu \mathrm{g} / \mathrm{l}, p=\mathrm{NS})$ were not significantly different at baseline or at the end of the study.

The metabolic effects of acipimox in 25 subjects are reported in Table 2. Anthropometric characteristics of the subjects were unaffected by acipimox treatment. However, acipimox was associated with a significant decrease in the fasting plasma non-esterified fatty acid concentration and an improvement in the 2-h plasma glucose, insulin-mediated glucose uptake, respiratory quotient and acute insulin response (Table 2). Fasting plasma glucagon, cortisol, and growth hormone concentrations were also significantly raised after acipimox. After controlling for the $2-\mathrm{h}$ plasma glucose, insulin-mediated glucose uptake, fasting plasma glucagon and growth hormone concentration, the acute insulin response $(41 \pm 3.3$ vs $52 \pm 4.7 \mathrm{mU} / 1, p<0.05)$ was still greater at the end of acipimox treatment than placebo treatment. After acipimox treatment, a significant correlation between the percentage decline in the fasting plasma non-esterified fatty acid concentration and an increase in the acute insulin response was also found $(r=0.64$, $p<0.006$, Fig. 2). This correlation persisted even after adjustment for change in the plasma glucagon, cortisol, growth hormone concentration and insulin-mediated glucose uptake $(r=0.49, p<0.01)$.

Comparing the acipimox group with the placebo group, acipimox was associated with a reduction in the 2-h plasma glucose value $(6.1 \pm 0.2$ vs $7.7 \pm 0.3 \mathrm{mmol} / \mathrm{l}, p<0.01)$; improvement in the insu-

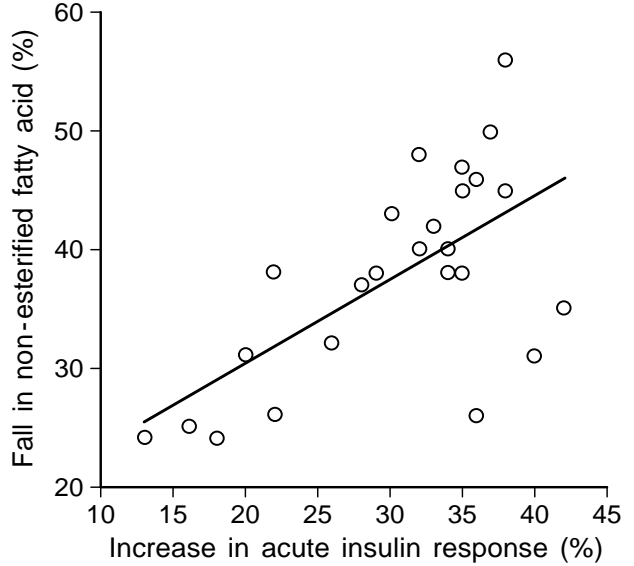

Fig. 2. Simple correlation between the percentage decrease in the fasting plasma non-esterified fatty acid concentration and an increase in the acute insulin response in first degree relatives of people with Type II diabetes treated by acipimox $(n=25)(r=0.64 p<0.006)$

lin-mediated glucose uptake $(35.4 \pm 0.5$ vs $28.3 \pm 0.4 \mu \mathrm{mol} / \mathrm{kg}$ fat free mass per min, $p<0.01)$, acute insulin response $(68 \pm 4.4$ vs $46 \pm 7.3 \mathrm{mU} / \mathrm{l}$, $p<0.01)$ and the respiratory quotient $(0.81 \pm 0.02 \mathrm{vs}$ $0.77 \pm 0.03, p<0.05)$ and a rise in the plasma glucagon $(164 \pm 63$ vs $134 \pm 72 \mathrm{ng} / \mathrm{l}, p<0.05)$, growth hormone $(1.31 \pm 0.13$ vs $0.97 \pm 0.21 \mu \mathrm{g} / \mathrm{l}, p<0.03)$ and cortisol (325 \pm 41 vs $284 \pm 139 \mathrm{nmol} / 1, p<0.05)$ concentrations. Difference in the acute insulin response persisted even after adjustment for the 2-h plasma glucose concentration, insulin-mediated glucose uptake, fasting plasma glucagon, and growth hormone concentration $(p<0.05)$.

Control study $(n=8)$. Baseline anthropometric, metabolic and hormonal data in the acipimox plus intralipid infusion and acipimox groups were not significantly different (data not shown). At the end of the study, the non-esterified fatty acid concentrations fasting plasma $(768 \pm 183$ vs $448 \pm 127 \mathrm{mmol} / \mathrm{l}$, $p<0.001)$ were higher in acipimox plus intralipid group than in acipimox group, while the fasting plasma glucose $(5.3 \pm 0.3$ vs $5.1 \pm 0.2 \mathrm{mmol} / 1, p=\mathrm{NS})$ and insulin ( $83 \pm 11$ vs $73 \pm 9 \mathrm{pmol} / \mathrm{l}, p=\mathrm{NS}$ ) concentrations were not significantly different in either group. In these metabolic conditions, the acute insulin response $(44 \pm 5.1$ vs $71 \pm 5.3 \mathrm{mU} / 1, p<0.01)$ and insulin-mediated glucose uptake $(27.4 \pm 0.4$ vs $36.7 \pm 0.5 \mu \mathrm{mol} / \mathrm{kg}$ fat free mass per min, $p<0.003$ ) were lower with acipimox plus intralipid treatment than with acipimox alone.

\section{Discussion}

Our study shows that acipimox treatment significantly improves the acute insulin response in first degree 
relatives of people with Type II diabetes. Several previous studies have indicated that healthy first degree relatives of people who have Type II diabetes have abnormalities in insulin action [12] and secretion [13], and thus have a greater risk of developing the diseases than people with no such family history. Why beta cell function is impaired in these subjects is still uncertain. It may result from long-term exposure to insulin resistance and a prolonged increasing demand for insulin secretion that eventually exceeds beta cell capacity (exhaustion) [17]. Lipotoxicity may be a further cause of beta cell desensitisation to glucose $[18,20]$. In fact, Zhou et al. [8] showed that long-term exposure of rat pancreatic islets to high non-esterified fatty acid concentrations inhibits glucose-induced insulin secretion and biosynthesis, probably via activation of the Randle cycle. Measures that lower the non-esterified fatty acid concentration $[18,22]$ have also been shown to be useful in preventing the development of hyperglycaemia and beta cell glucose incompetence in pre-diabetic rats. Longterm (24-h) intralipid infusion and intravenous glucose tests showed significant inhibition of the acute insulin response [9], but these data were not confirmed by the hyperglycaemic glucose clamp procedure [10]. Nevertheless, it is most likely that continuous hyperglycaemia offsets the negative impact on glucose-induced insulin secretion of the beta cell Randle cycle overactivity, which, in turn, occurs when the raised fasting plasma non-esterified fatty acid concentration is associated with euglycaemia.

In our study, fasting plasma non-esterified fatty acid concentrations were high, particularly if one considers that in an age-, sex-, and weight-matched control population $(n=50)$ of healthy subjects with no family history of diabetes, a low fasting plasma nonesterified fatty acid concentration was found $(375 \pm 78 \mu \mathrm{mol} / 1, p<0.001$ vs the concentration in our group). However, high fasting plasma non-esterified fatty acid concentrations in the offspring of lean parents with Type II diabetes were also found by Perseghin et al. [23]. In fact, these authors showed values close to $600 \mathrm{mmol} / \mathrm{l}$ in a population study very similar to ours.

Both deficient insulin secretion and impaired insulin-mediated glucose uptake could account for such an increase in the fasting plasma non-esterified fatty acid concentration in first-degree relatives of people with Type II diabetes. In these people, long-term exposure of beta cells to high fasting non-esterified fatty acid concentrations could derange glucose-stimulated insulin secretion through lipotoxicity. Such a hypothesis is strengthened by the following observations. Firstly, in the whole group $(n=50)$, there was a negative correlation between the fasting plasma non-esterified fatty acids concentration and the acute insulin response a correlation that persisted even after adjustment for the main anthropometric (body fat) and metabolic (2-h plasma glucose and insulinmediated glucose uptake) confounders. Secondly, in the multivariate analysis, the fasting plasma non-esterified fatty acids concentration was significantly and independently associated with the acute insulin response.

If an increased islet non-esterified fatty acid concentration causes the beta cell changes of Type II diabetes, the abnormalities should be preventable by measures that reduce the substrate overload. Several compounds with antilipolytic activity have been reported to be effective in reducing hyperglycaemia, but their effect on islet function has been not characterised. Acipimox is one of these compounds. Its administration is associated with a significant improvement in insulin-mediated glucose uptake [24] and a rise in the plasma glucagon, growth hormone and cortisol concentrations [25].

To the best of our knowledge, no study has yet investigated the effect of acipimox on glucose-induced insulin secretion. In our study, acipimox treatment compared with placebo was associated with a significant reduction in the non-esterified fatty acid fasting plasma concentration and a significant increase in glucose-induced insulin secretion. This result provides further evidence that hyperlipidaemia might share responsibility for the derangement of beta cell function in our subjects. One could argue that after acipimox administration a significant rise in the plasma glucagon concentration also occurs, a phenomenon that might be responsible for a potentiation of glucose-induced insulin secretion. Nevertheless, the difference in the acute insulin response between acipimox and placebo persisted even after controlling for the main metabolic parameters. Furthermore, the correlation between the percentage increase in the acute insulin response and the decline in the fasting plasma non-esterified fatty acid concentration was found to be independent of changes in plasma glucagon, cortisol and growth hormone concentrations and in insulin-mediated glucose uptake. Despite the fact that ANCOVA or partial correlation can not prove a pathophysiological link, we believe that such statistical evidence may strengthen the hypothesis that a reduction in the non-esterified fatty acid concentration induced by acipimox may improve the acute insulin response. Finally, in the control study acipimox treatment (independently of changes in the non-esterified fatty acid plasma concentration) did not affect the acute insulin response and insulin-mediated glucose uptake.

In conclusion, our study shows that in first degree relatives of people with Type II diabetes, high fasting plasma non-esterified fatty acid concentrations are associated with a poor glucose-induced insulin secretion and insulin resistance. Long term treatment with acipimox lowers the fasting plasma non-esterified fatty acid concentration and improves both glu- 
cose-induced insulin secretion and insulin action. Our data make a further contribution to the lipotoxicity hypothesis for explaining the genesis of beta cell failure in patients with Type II diabetes.

\section{References}

1. Groop LC, Bonadonna RC, Del Prato S, Rathiesz K, Zyck K, Ferrannini E, De Fronzo RA (1989) Glucose and free fatty acids metabolism in non.insulin dependent diabetes mellitus: evidence for multiple sites of insulin resistance. $\mathrm{J}$ Clin Invest 84: 205-213

2. Groop LC, Saloranta C, Shank M, Bonadonna RC, Ferrannini E, De Fronzo RA (1991) The role of free fatty acids metabolism in the pathogenesis of insulin resistance in obesity and non-insulin dependent diabetes mellitus. J Clin Endocrinol Metab 72: 96-107

3. Paolisso G, Tataranni A, Foley JE, Bogardus C, Howard BV, Ravussin E. (1995) High concentration of fasting plasma non-esterified fatty acids is a risk factor for the development of NIDDM. Diabetologia 38: 1213-1217

4. Milburn JL, Hirose H, Lee YH et al. (1995) Pancreatic $\beta$ cells in obesity: evidence for functional, morphologic and metabolic abnormalities by increased long-chain fatty acids. J Biol Chem 270: 1295-1299

5. Hirose H, Lee YH, Iuman LR, Nagasawa Y, Johnson JH, Unger RH (1996) Defective fatty acid mediated cell compensation in Zucker-diabetic fatty rats. J Biol Chem 271: 5633-5637

6. Crespin SR, Greenough WB, Steinberg D (1973) Stimulation of insulin secretion by long-chain free fatty acids. J Clin Invest 52: 1979-1984

7. Prentki M, Vischer S, Glennon MC, Regazzi R, Deeney JT, Corkey BE (1992) Malonyl-CoA and long-chain acyl-CoA esters as metabolic coupling factor in nutrients-induced insulin secretion. J Biol Chem 267: 5802-5810

8. Zhou YP, Grill V (1994) Long-term exposure of rat pancreatic islet to fatty acids inhibits glucose-induced insulin secretion and biosynthesis through a glucose fatty acid cycle. J Clin Invest 93: 870-876

9. Paolisso G, Gambardella A, Amato L, Tortoriello R, D'Amore A, Varricchio M, D'Onofrio F (1995) Opposite effects of short- and long-term fatty acid infusion on insulin secretion in healthy subjects. Diabetologia 38: 1295-1299

10. Boden G, Chen X, Rosnar J, Barton M (1995) Effect of a $48 \mathrm{~h}$ fat infusion on insulin secretion and glucose utilization. Diabetes 44: 1239-1242

11. Eriksson J, Froussila-Kallunki A, Ekstand A, Saloranta C, Widen E, Schalin C, Groop L (1989) Early metabolic defects in persons at increased risk for non-insulin dependent diabetes mellitus. N Engl J Med 321: 337-343
12. Warram J, Martin B, Krolewski A, Soelleuer S, Kahn C (1990) Slow glucose removal rate and hyperinsulinemia precede the development of type II diabetes in the offspring of diabetic patients. Ann Intern Med 113: 909-915

13. Pimenta W, Korytkoeski M, Mitrokon A et al. (1995) Pancreatic $\beta$-cell dysfunction as the primary genetic lesion in NIDDM. Evidence from studies in normal glucose tolerant individuals with first degree NIDDM relative. JAMA 273: 1855-1861

14. World Health Organization (1985) Diabetes mellitus: Report of WHO study group. World Health Organization, Geneva (Technical Report Series 727: 9-17)

15. Ferrannini E (1990) The theoretical basis of indirect calorimetry: methodological and interpretative problems. Metabolism 258: 339-342

16. Dole VP, Meinertz H (1960) Microdetermination of longchain fatty acids in plasma and tissues. J Biol Chem 235: 2595-2599

17. Saad MF, Knowler WC, Pettitt DJ, Nelson RG, Charles MA, Bennett P (1990) A two step model for the development of non-insulin dependent diabetes. Am J Med 90: 229-235

18. Unger RH (1995) Lipotoxicity in the pathogenesis of obesity-dependent NIDDM. Genetic and clinical implications. Diabetes 44: 863-870

19. Sako Y, Grill V (1990) A $48 \mathrm{~h}$ lipid infusion in the rat timedipendently manner inhibits glucose-induced insulin secretion and $\beta$-cell oxidation through a process likely coupled to fatty acid oxidation. Endocrinology 127: 1580-1589

20. Capito K, Hansen SE, Healeskov CJ, Thomas PJ (1992) Fat induced changes in mouse pancreatic islets, insulin secretion, insulin biosynthesis and glucose metabolism. Acta Diabetol 28: 193-198

21. Ohneda M, Inman LR, Unger RH (1995) Caloric restriction in obese pre-diabetic rats prevents $\beta$-cell depletion, loss of $\beta$-cell GLUT2 and glucose incompetence. Diabetologia 38: 173-179

22. Brun T, Jeannet-Assimacopoulos F, Corkey BE, Prentki M (1997) Long-chain fatty acid inhibit acetyl-CoA carboxylase gene expression in the pancreatic $\beta$-cell Line INS- 1 . Diabetes 46: 393-400

23. Perseghin G, Ghosh S, Gerow K, Shulman GI (1997) Metabolic defects in lean nondiabetic offspring of NIDDM parents: a cross-sectional study. Diabetes 46: 1001-1009

24. Fulcher GR, Walker M, Catalano C, Agius L, Alberti KGMM (1992) Metabolic effects of suppression of non-esterified fatty acids levels with acipimox in obese NIDDM subjects. Diabetes 41: 1400-1408

25. Saloranta C, Taskinen MR, Widen E, Harkonen M, Melander A, Groop L (1993) Metabolic consequences of sustained suppression of free fatty acids by acipimox in patients with NIDDM. Diabetes 42: 1559-1566 